\title{
Nutritional Status in Elderly People Living in Retirement Homes in the Czech Republic
}

\author{
Jolana Rambousková, Eva Kř́žová, Pavel Dlouhý, \\ Jana Potočková and Michal Anděl
}

\section{Introduction}

The population of the Czech Republic (CR) is approximately 10 million inhabitants. It presents $2.3 \%$ of the extended EU population. In the Czech

1 Republic the older population percentage is rapidly increasing due to the increase in life expectancy (M 73 yrs, F 79 yrs) and an extremely low birth rate, which has existed since the 1990's (fertility rate increased slightly from minimum 1.13 in 1999 to 1.44 in 2006). In 2007, 15\% of inhabitants were aged 65+ (more than 1.5 mil.), by 2030 the $65+$ population is expected to reach $22.8 \%$, and by 2050, it is expected to be $31.3 \%$. The proportion of persons in the highest age group (85+) is growing the most rapidly and increases in life expectancy, in both sexes, is expected to continue, with estimated life expectancies of 84 years in males and 88 years in females by 2065 . The relative share of seniors will unevenly increase in coming decades due to natural ageing of the early 1970's "population boom," which was a direct consequence of pro-birth measures linked to social policies of political "normalization". The age structure in the CR, measured by the age preference index, is currently on par with the EU average, however, if present trends persist, the population of the CR will gradually become one of the oldest in Europe. ${ }^{1}$ Health insurance of pensioners, in the CR, is financed from the state budget. Traditionally, provision for health and social care was concentrated in modern institutions (hospitals, elderly homes, residential nursing homes, etc.). It is only recently that small steps, involving new trends of extramural care (e.g. home care) have been taken and political support for independent living and family care has only recently, been declared. Nonetheless, rising financial stress on the health care budget and persistent mental and organizational stereotypes and traditions

1 Institute of Health Information and Statistics of the Czech Republic, http://www.uzis.cz (July 16, 2010). 
(giving priority to large professional health and social care institutions instead of small independent outpatient providers or lay care) have caused implementation of reforms to lag behind practical needs. During the 1990's, decentralization and privatization led to diversification of providers, especially in out-patient health care, nursing care, and social services. The senior population is heterogeneous when viewed from health, mental, social and/or economic perspectives; however, the inequalities have not yet been systematically studied, despite the high political value of equity. The only exception may be the regional differences in life expectancy, mortality, and accessibility to health care, which have been systematically monitored by the national health statistical system. ${ }^{2}$

Nutritional status of the elderly is a basic determinant of health and disease. Based on our experiences, the majority patients 75 years of age and older, admitted to hospital, are undernourished. For one third of all admitted patients, in this age group, malnutrition or water and electrolyte disturbances represent basic etiopathogenic factors, which are associated with other morbidities. Undernutrition in the elderly develops due to reduced intake of food, a natural part of the aging process, and decreased physical activity. Stress metabolism associated with major surgery or critical illness e.g., severe infection, may be the reason for disease-related undernutrition in all patients regardless of age, whereas in elderly patients, multi-morbidity and reduced reserve capacity may increase the risk for undernutrition in excess of that seen in younger patients. ${ }^{3}$ A study by German et al. ${ }^{4}$ found a significant association between depression and risk for undernutrition among hospitalized elderly patients. Overall, $17 \%$ of hospitalized elderly patients were both depressed and at risk for undernutrition as assessed using a self-reporting questionnaire. ${ }^{5}$

Experience has shown that socioeconomics is not the main problem with regard to undernutrition in the elderly. Regardless of whether the elderly are living in prosperous families, or, as is more common for the elderly, living in retirement homes and the other social institutions, undernutrition is still an issue. A consequence of undernutrition is reduced protein synthesis, which weakens the immune system and puts the elderly at increased risk of infections (e.g. bronchopneumonia,

2 Preliminary National Report on Health Care and Long-term Care in the Czech Republic, http://www.mpsv.cz/files/clanky/1343/report health care.pdf (July 16, 2010).

3 Ilana Feldblum, Larisa German, Natalya Bilenko, A Shahar, R Enten, D Greenberg, Ilana Harman-Boehm, Hana Castel, Danit R Shahar, „ Nutritional Risk and Health Care Use before and after an Acute Hospitalization among the Elderly“, Nutrition, 25 (2009), pp. 415-420.

4 Larisa German, Ilana Feldblum, Natalya Bilenko, Hana Castel, Ilana Harman-Boehm, Danit R Shahar, „Depressive Symptoms and Risk for Malnutrition among Hospitalised Elderly People“, J Nutr Health Aging, 12 (2008), pp.313-318.

5 Ilana Feldblum, Larisa German, Hana Castel, Ilana Harman-Boehm, Natalya Bilenko, Miruna Eisinger, Drora Fraser, Danit R Shahar, „Characteristics of Undernourished Older Medical Patients and the Identification of Predictors for Undernutrition Status", Nutritional Journal, 6 (2007), pp. 1-9. 
urinary infections). Additionally, wound and fracture healing can also be prolonged. Malnutrition is also related to dehydration. The consequences of dehydration initially present as poor perfusion of organs, which is associated with increased risk of renal failure, urinary tract infections, cerebral apoplexy, and hepatic lesions. The second consequence is higher blood viscosity, which is associated with increased risk of thrombosis, pulmonary embolism, heart attack, cerebral apoplexy, and renal failure. ${ }^{6}$ Currently, there is lack of studies regarding the nutritional status of frail elderly in the Czech Republic. Elderly people can live at home alone, or with their immediate or extended family (for the purpose of this study these types of living arrangements are referred to as "residential settings") or in retirements homes, rest homes, nursing homes or senior housing (these types of living arrangements are referred to as "institutional facilities"). The goal of our study was to evaluate the nutritional status of elderly individuals admitted to hospital. Additionally, we compared the nutritional status of those coming from family homes with those coming from institutional facilities.

\section{Methods}

The study sample consisted of 281 patients (101 men and 180 women) older than 70 years, who were admitted to the $2^{\text {nd }}$ Department of Internal Medicine, University Hospital, Královské Vinohrady during a three month period (1.1.2006 31.3.2006). Patients with any stage of malignant tumor were excluded from the study. All basic data were collected by well-trained internists within 2 days of admission and 1 day before discharge from hospital. The anthropometric measurements were taken by trained staff and included weight, height and body-mass index (BMI), which was estimated by dividing weight $(\mathrm{kg})$ by height ${ }^{2}\left(\mathrm{~m}^{2}\right)$. Blood samples were obtained at admission and before discharge and were analyzed by the Department of Biochemistry and Pathobiochemistry of the University Hospital, Královské Vinohrady. Two groups of patients were compared: patients living in institutional facilities for seniors (e.g. retirement homes) and elderly patients who lived in residential settings. The difference between groups was measured using Fishers Exact Test and the Wilcoxon Two-Sample Test. Data are expressed as means \pm SDs for continuous variables and as percentages for categorical variables. Intergroup differ-

6 Michal Anděl, Pavel Dlouhý, Jolana Rambousková, Dana Kubisová, Pavel Těšínský, Pavel Kraml, Nutritional Problems and Nutritional Support in Elderly (Problematika výživy a nutriční podpora ve stáŕí).In: Michal Anděl, Luboš Sobotka, Pavel Těšínský, Zdeněk Zadák, Influence of the nutrition and intensive medical care at the organs funcion and postoperative status (Vliv výživy a intenzivní metabolické péče na orgánové funkce a pooperační stavy) Hradec Králové, Nucleus (2003), pp. 98-100. 
ences and correlations were tested, and P values of less than 0.05 were accepted as statistically significant.

\section{Results}

The study group consisted of 281 patients aged $\geq 70$ years $(101$ male and 180 female) who were admitted to hospital. Age range for patients is presented in Table 1. Table 2 shows patient living/care arrangements prior to hospitalization and table 3 shows the patient living/care arrangements after discharge. Mean body mass index (BMI) was $26.71 \pm 5.47 \mathrm{~kg} / \mathrm{m}^{2}$ in patients coming from a residential setting, $27.25 \pm$ $6.81 \mathrm{~kg} / \mathrm{m}^{2}$ in patients coming from institutional facilities and $23.77 \pm 5.36 \mathrm{~kg} / \mathrm{m}^{2}$ in patients transferred from another department. The mean serum albumin concentration on admission was $<30 \mathrm{~g} / \mathrm{l}$ in $22.3 \%$ of patients coming from a residential setting and $34.1 \%$ of patients coming from institutional facilities (Table 4). Blood albumin concentrations on hospital discharge are shown in table 5. There was significant difference between the group of patients discharging to a residential setting and patients discharging to institutional facilities.

Table 1. Age range of study participants.

\begin{tabular}{cccc}
\hline Age (years) & Male & Female & Total \\
\hline $70-74.99$ & 35 & 29 & 64 \\
$75-79.99$ & 24 & 63 & 87 \\
$80-84.99$ & 22 & 44 & 66 \\
$85-89.99$ & 11 & 27 & 38 \\
$90-94.99$ & 9 & 14 & 23 \\
$\geq 95$ & 0 & 3 & 3 \\
Total & 101 & 180 & 281 \\
\hline
\end{tabular}

Table 2. Living arrangements prior to hospitalization.

\begin{tabular}{lccc}
\hline & Male & Female & Total \\
\hline Residential & 83 & 153 & 236 \\
Institutional & 15 & 24 & 39 \\
Another department & 4 & 2 & 6 \\
Total & 102 & 179 & 281 \\
\hline
\end{tabular}


Table 3. Living arrangements after hospitalization.

\begin{tabular}{lccc}
\hline & Male & Female & Total \\
\hline Residential & 67 & 116 & 183 \\
Institutional & 12 & 30 & 42 \\
Another department & 14 & 17 & 31 \\
Died & 9 & 16 & 25 \\
Total & 102 & 179 & 281 \\
\hline
\end{tabular}

Table 4. Blood albumin on hospital admission (\% of patient with low and normal values) $\mathrm{SD}$, standard deviation.

\begin{tabular}{lccc}
\hline & Alb $<\mathbf{3 0} \mathbf{g} / \mathbf{l}$ & Alb $\geq \mathbf{3 0} \mathbf{g} / \mathbf{l}$ & p-value \\
\hline Residential & 22.3 & 77.7 & 0.008 \\
Institutional & 34.1 & 65.9 & \\
\hline
\end{tabular}

Table 5. Blood albumin on hospital discharge (means and SD).

\begin{tabular}{lccc}
\hline & albumin $(\mathrm{g} / \mathrm{l})$ & SD & p-value \\
\hline Residential $(\mathrm{n}=178)$ & 34.624 & 5.946 & 0.003 \\
Institutional $(\mathrm{n}=41)$ & 30.304 & 6.924 & \\
\hline
\end{tabular}

\section{Discussion}

We decided to compared patients coming from residential setting and those coming from institutional facilities because there is evidence for nutritional problems in frail, institutionalized elderly residents. ${ }^{7,8}$

Undernutrition as measured by BMI and albumin serum concentration is common in those admitted to a subacute-care facility. A study by Poulsen ${ }^{9}$ found undernutrition in $41 \%$ of patients at admission to a geriatric clinic using a BMI $\left(\mathrm{kg} / \mathrm{m}^{2}\right)$ cut-off of 22 . Morley and Thomas ${ }^{10}$ attribute the "anorexia of aging" to a disturbance in the ability to regulate food intake. The poor nutritional status of the elderly can be attributed to multiple factors. With increasing age, appetite is reduced, physical activity diminishes, and fat-free body mass decreases even in

7 Daniela Kulnik, Ibrahim Elmadfa, „Assessment of the Nutritional Situation of Elderly Nursing Home Residents in Vienna“, Ann Nutr Metab, 52(suppl 1) (2008), pp. 51-53.

8 David R Thomas, Carolyn D Zdrowski, Margaret-Mary Wilson, Kelly C Conright, Cecelia Lewis, Syed Tariq, John E Morley, „Malnutrition in Subacute Care“, Am J Clin Nutr, 75 (2002), pp. 308-313.

9 Ingrid Poulsen, Ingalill Rahm Hallberg, Marianne Schroll, „Nutritional Status and Associated Factors on Geriatric Admission“, J Nutr Health Aging, 10 (2006), pp. 84-90.

10 John E Morley, David R Thomas, "Anorexia and aging: pathophysiology" Nutrition, 15 (1999), pp. 499-503. 
absence of an overt catabolic illness. Despite the high prevalence of malnutrition in the elderly and the known association between malnutrition and poor clinical outcomes, malnutrition often goes unrecognized and untreated during hospitalization. This is partly because routine nutritional tests, in current use, are often not done because of time constraints and, in part, because of the frailty of geriatric patients. Anthropometric measurements are crucial part of nutritional assessments and are considered the most significant part of the mini nutritional assessment (MNA). Low serum albumin concentration, diabetes mellitus, infections, and malignancy have been found to be independent risk factors for death. ${ }^{11}$ In this study, blood albumin levels were used in the assessment of nutritional status and albumin levels $\leq 30 \mathrm{~g} / \mathrm{l}$ was taken as the cut-off point for undernutrition. Most patients came from a residential setting and $77.7 \%$ of them had blood albumin levels $\geq 30 \mathrm{~g} / \mathrm{l} .65 .9 \%$ of patients coming from institutional facilities had blood albumin levels $\geq 30 \mathrm{~g} / \mathrm{l}$. More than one-half of the subjects admitted to subacute care had low serum albumin concentrations. Severity of protein-energy undernutrition, as indicated by a low serum albumin concentration or a history of recent involuntary weight loss, is a strong independent risk factor for life-threatening morbidity after discharge from a rehabilitation facility, even when the severity of illness is controlled. ${ }^{12}$ In a Swedish study, $29 \%$ of patients admitted to a long-term-care geriatric hospital were malnourished at admission. ${ }^{13}$ Serum albumin concentration is inversely related to mortality risk in a graded manner; the estimated increase in the odds of death ranges from $24 \%$ to $56 \%$ for each $2.5 \mathrm{~g} / \mathrm{l}$ decrement in serum albumin concentration. ${ }^{14}$

\section{Conclusions}

In this study, BMI did not differ between patients coming from residential settings and patients coming from institutional facilities. Thirty percent of all patients admitted to hospital had biochemical signs of decreased protein synthesis (data not shown). Low blood albumin levels were found in $34.1 \%$ of patients from institutional facilities and $22.3 \%$ of patients coming from residential settings. Malnutri-

11 Nadya Kagansky, Yitshal Berner, Nira Koren-Morag, Luiza Perelman, Hilla Knobler, Shmuel Levy, „Poor Nutritional Habits are Predictors of Poor Outcome in Very Old Hospitalized Patients", Am J Clin Nutr, 82 (2005), pp. 784-791.

12 Dennis H Sullivan, Robert C Walls, Melinda M Bopp, "Protein-energy undernutrition and the risk of mortality within one year hospital discharge: a follow-up study" J Am Geriatr Soc, 43 (1995), pp. 507-512.

13 J Larsson, M Unosson, A-C Ek, L Nilsson, S Thorslund, P Bjurulf, Effect of dietary supplement on nutritional status and clinical outcome in 501 geriatric patients--a randomized study. Clin Nutr, 9 (1990), pp.179-184.

14 Philip Goldwasser, Joseph G Feldman, Association of serum albumin and mortality risk, J Clin Epidemiol, 50 (1997), pp. 693-703. 
tion and metabolism disorders represent a fundamental cause of hospitalization in the elderly. These patients' often require long-term hospitalization as well as substantial post-hospitalization care. Such care represents a financial burden for hospitals and institutional care facilities.

There is evidence of poor nutritional status among residents in institutional facilities. There have been no studies comparing nutritional statuses, relative to regional differences, in institutional faculties (i.e. large vs. small towns, rural vs. urban populations). It is precisely the absence of these studies that differentiates the Czech Republic from many other developed or developing countries. ${ }^{15}$ For these reasons, we would like to focus our future studies on defining the nutritional status of elderly patients who reside in institutional facilities. We plan, over the next years, to carry out an assessment of the nutritional status of elderly living in institutional facilities and analyze regional differences. We would like to compare two groups: the first group of elderly would be from Prague and the second group would be from a small city.

Jolana Rambousková is $\mathrm{MD}, \mathrm{PhD}$, Eva Křžová is Doctor of Philosophy, $\mathrm{PhD}$, Pavel Dlouhy is MD, PhD, Michal Andèl is MD, PhD, Professor of Medicine Department of Nutrition, Third Faculty of Medicine, Charles University in Prague.

\section{Acknowledgements}

This study was supported by a grant from The Ministry of Health of the Czech Republic NS9972-4/2008 and by the research program of the $3^{\text {rd }}$ Faculty of Medicine No. MSM 0021620814 ("Prevention, diagnostics and therapy of diabetes mellitus, metabolic and endocrine damage of organism").

15 Stephanie Lesser, Lioba Pauly, Dorothee Volkert, Peter Stehle, Nutritional Situation of the Elderly in Eastern/Baltic and Central/Western Europe - The Ageing Nutrition Project" Ann Nutr Metab, 52 (suppl) (2008), pp. 62-71. 


\section{References}

Anděl, M, Dlouhý, P, Rambousková, J Kubisová, D, Těšínský, P, Kraml, P, "Nutritional Problems and Nutritional Support in Elderly" (Problematika výživy a nutriční podpora ve stáríi).In: Anděl,M Sobotka, L, Těšínský, P, Zadák, Z, Influence of the nutrition and intensive medical care at the organs funcion and postoperative status (Vliv výživy a intenzivní metabolické péče na orgánové funkce a pooperační stavy) Hradec Králové, Nucleus (2003), pp. 98100.

Feldblum, I German, L, Bilenko, N, Shahar, A, Enten, R, Greenberg, D, HarmanBoehm, I, Castel,H, Shahar, DR, "Nutritional Risk and Health Care Use before and after an Acute Hospitalization among the Elderly", Nutrition, 25 (2009), pp. 415-420.

German, L, Feldblum, I, Bilenko, N, Castel, H Harman-Boehm, I, Shahar, DR "Depressive Symptoms and Risk for Malnutrition among Hospitalised Elderly People“, J Nutr Health Aging, 12 (2008), pp.313-318.

Feldblum, I, German, L Castel,H, Harman-Boehm, I, Bilenko, N, Eisinger,M, Fraser, D, Shahar, DR, "Characteristics of Undernourished Older Medical Patients and the Identification of Predictors for Undernutrition Status", Nutritional Journal, 6 (2007), pp. 1-9.

Goldwasser, P, Feldman, JG, "Association of serum albumin and mortality risk", $J$ Clin Epidemiol, 50 (1997), pp. 693-703.

Institute of Health Information and Statistics of the Czech Republic, http://www.uzis.cz (July 16, 2010).

Kagansky, N, Berner, Y, Koren-Morag, N, Perelman, L, Knobler, H, Levy, S,

"Poor Nutritional Habits are Predictors of Poor Outcome in Very Old Hospitalized Patients", Am J Clin Nutr, 82 (2005), pp. 784-791.

Kulnik,"D, Elmadfa, I, "Assessment of the Nutritional Situation of Elderly Nursing Home Residents in Vienna”, Ann Nutr Metab, 52 (suppl 1) (2008), pp. 51-53.

Larsson, J, Unosson, M, Ek, A-C, Nilsson, L, Thorslund, S, Bjurulf, P, "Effect of dietary supplement on nutritional status and clinical outcome in 501 geriatric patients--a randomized study". Clin Nutr, 9 (1990), pp.179-184.

Lesser, S, Pauly, L, Volkert, D Stehle, P. "Nutritional Situation of the Elderly in Eastern/Baltic and Central/Western Europe - The Ageing Nutrition Project" Ann Nutr Metab, 52(suppl) (2008), pp. 62-71.

Morley, JE, Thomas, DR, "Anorexia and aging: pathophysiology" Nutrition, 15 (1999), pp. 499-503.

Thomas, DR, Zdrowski, CD, Wilson, M-M, Conright, KC, Lewis, C, Tariq, S, Morley, JE, "Malnutrition in Subacute Care", Am J Clin Nutr, 75 (2002), pp. 308-313. 
Poulsen, J, Rahm Hallberg, I, Schroll, M, "Nutritional Status and Associated Factors on Geriatric Admission", J Nutr Health Aging, 10 (2006), pp. 84-90.

Preliminary National Report on Health Care and Long-term Care in the Czech Republic, http://www.mpsv.cz/files/clanky/1343/report health care.pdf (July 16, 2010).

Sullivan, DH, Walls, RC, Bopp, MM, "Protein-energy undernutrition and the risk of mortality within one year hospital discharge: a follow-up study" $J \mathrm{Am}$ Geriatr Soc, 43 (1995), pp. 507-512. 